\title{
SPINAL CORD INJURY BY FALLS: COMPARISON BETWEEN SUICIDAL AND ACCIDENTAL CASES
}

\author{
By R. Girard, P. Minaire, M. Castanier, E. Berard, and B. Perrineriche* \\ Hôpital Henry Gabrielle-69230 Saint Genis Laval, France
}

\begin{abstract}
The computer study of 783 paraplegics treated at H. Gabrielle hospital has been presented in 1977 at Stoke Mandeville.

This study allows a useful comparison between suicidal by defenestration mean and accidental falls and confirms the clinical impression of a most favourable evolution for the suicide.
\end{abstract}

\section{The Population}

The series includes 783 paraplegics, from whom 525 were traumatic. Of all the falls, are taken off the sports cases $(7.6$ per cent, from whom 3.5 per cent diving) to be sure to have comparable populations: 132 accidental falls from a roof, a scaffolding, a scale, a tree . . 24.7 per cent of all traumatic paraplegics and 24 suicidal cases- 4.5 per cent of the traumatic.

\section{Time of occurrence}

A similar number of cases each year, but the monthly pattern is different: suicides occur in June-July (40 per cent) and from September to December (40 per cent), none in April or in August. Accidents are more regularly distributed.

\section{Age and Sexual Distribution}

The voluntary jumpers are young (58.3 per cent have been less than 30 years) and females (I8, that corresponds to 15.5 per cent of the female population) and only six men ( $\mathrm{I} \cdot 4$ per cent of the male paraplegics). On the other hand are the accidental falls: were all men, and with an elevation of the eldest.

\section{Professions}

$47^{\circ} 6$ per cent of suicides are not working (versus 14.3 per cent), and the accidents correspond very often to a professional injury.

A psychiatric previous history for 90 per cent of the suicides, the defenestration is more often the first suicidal attempt and occurring in the third of the cases during treatment in a psychiatric hospital.

\section{Level of Lesions}

(a) Vertebral lesions: same level for thoracic and TI2-LI, but differs for cervical and lumbar (cf. table) voluntary jumpers have $24 \cdot \mathrm{I}$ per cent of lumbar

* Service de Rééducation Fonctionnelle (Professeur J. Bourret). 
and 6.9 per cent of cervical dislocation versus respectively, 8 per cent and I8.4 per cent for the other group.

(b) Spinal cord lesions: the difference is much more evident: with suicides, the thoraco-lumbar levels are much more common (cf. table).

The associated lesions of defenestration are characteristic of those seen after vertical fall: feet, hip.

To sum up, the defenestration paraplegia occurs preferentially among young women not working, with a previous psychiatric history. The vertebral and spinal cord lesions are, above all, thoraco-lumbar. And in spite of frequent lower limb associated lesions, they are leaving hospital and returning home after the shortest average time of 183 days compared to the other aetiologies. For example, 244 days after an accidental fall.

TABLE I

\begin{tabular}{|c|c|c|}
\hline Number & $\begin{array}{l}\text { Defenestration } \\
24(4.5 \%)\end{array}$ & $\begin{array}{c}\text { Accidental falls } \\
\text { I33 }(29 \cdot 2 \%)\end{array}$ \\
\hline $\begin{array}{l}\text { Vertebral level } \\
\text { Cervical } \\
\text { High thoracic } \\
\text { Low thoracic } \\
\text { Thoraco-lumbar } \\
\text { Lumbar }\end{array}$ & $\begin{array}{r}6 \cdot 9 \% \\
20 \cdot 7 \% \\
10 \cdot 3 \% \\
37 \cdot 7 \% \\
24 \cdot 1 \%\end{array}$ & $\begin{array}{l}\text { I } 8 \cdot 4 \% \\
\text { I I. } 0 \% \\
22 \cdot 8 \% \\
39 \cdot 7 \% \\
8 \cdot 0 \%\end{array}$ \\
\hline $\begin{array}{l}\text { Spinal cord level } \\
\text { Tetraplegia } \\
\text { T2-T6 } \\
\text { T7-TII } \\
\text { TI2-LI } \\
\text { L2-S5 }_{5} \\
\text { Cauda equina } \\
\text { Associated fractures of } \\
\text { lower limbs-pelvis }\end{array}$ & $\begin{array}{r}9.1 \% \\
\mathrm{I} 8.2 \% \\
4.6 \% \\
\mathrm{I} 8.2 \% \\
45.5 \% \\
4.5 \% \\
62.0 \%\end{array}$ & $\begin{array}{r}25 \cdot 6 \% \\
14 \cdot 0 \% \\
20 \cdot 6 \% \\
13 \cdot 2 \% \\
24 \cdot 8 \% \\
1 \cdot 7 \%\end{array}$ \\
\hline
\end{tabular}

\section{Literature}

Comparison with other statistical studies is difficult, because the suicidal attempts have not been individualised among the falls (Frankel, 1969; Sutton, I973; Kraus, I975).

Papers are scarce about paraplegia after defenestration. Hoff and Chapman (1974) have found 12 cases out of 204 vertebral fractures treated from 1963 to I978 at the University of California, San Francisco. They insist on the psychiatric characteristics-they were all members of the Beat generation, drug users and suffered from schizophrenia or sociopathic personality. Concerning the sex ratio, they are seven women and five men, average age 29 years. Jumps from various heights 3 , to $\mathrm{I} 3$, metres and most landed feet first. Twenty-four vertebral fractures: I5 of TII-TI2 and LI, five from L2-L5, two cervical and two from Ti-Tio. Each of them had, at least, one fracture among the Ti2 and L2 vertebral.

Of the same manner, they had associated injuries of lower limbs and of pelvis. Only seven neurologic lesions: four definitive paraplegia (unknown levels), three paraparesies with a good recovery. 


\section{Pathogeny}

Importance of heights. There seems to be a parallelism between the height of the jump and the level of the vertebral lesion. The series is not numerous enough to give a scientific proof, but it is of value to note that low jumps from Ist or 2nd floors are responsible for cervical injuries with cranial and chest associated lesions; and the higher ones, of thoraco-lumbar and sacral levels, with lesion of lower levels (feet, etc.).

This is obvious with divers who jump head first but also with other accidental falls: for example, from fruit trees and cherry trees. But provided the height is enough, it is to be supposed that the body in space tilts over on itself because of gravity and lands feet first. Everybody remembers the paper of Dr Toe in Stoke Mandeville (1977): in Rangoon, the fruit trees are very high coconut trees, where people climb and occasionally fall down, provoking 70 per cent of all paraplegics and they are of a thoraco-lumbar area.

In case of fall on the feet, the thoraco-lumbar sacral level of lesion is well explained (cf. Rotondo, I975). In that position, the percentages of body loads applied on a single vertebra increase from cervical- 7 per cent of total body weight; thoracic-25 per cent at T6, to lumbar-50 per cent at LI and 60 per cent at L5 level.

However, the differences of level and the better evolution among suicidal paraplegia are not perfectly explained by a question of height. They also depend on another factor.

The suicidal attempt is a vertical jump with relaxed muscles. And it may be usefully compared with the voluntary jumps of paratroops and of jet pilots. The parachute landing gives a low frequency of vertebral lesions with thoracolumbar level (cf. Teyssandier).

Rotondo reports his experiment on a spinal injury after ejection in jet pilots (23 thoraco-lumbar fractures among I5 pilots-no paraplegia). The considerable jolt given to the pilot's body by the blast charge beneath the seat in case of emergency ejection reaches a considerable acceleration in foot-head direction. For a pilot weighing $70 \mathrm{~kg}$, the load at Ti level is of I40-210 kg and at L5 level $420-630 \mathrm{~kg}$.

Allowing for the body constitution, the weak-point of the spine is TII-TI2 and $\mathrm{LI}_{\mathrm{I}}$ in normal typical subjects and T6-T8 in longitudinal ones. The position of the spine is also important when the pilot bends the trunk forward during ejection; with kyphotic attitude, the new spinal curve exposes T6 and L3.

The part played by muscular tonicity is underlined by the experiment of Verriest et al, on baboons: the contraction of vertebral muscles reduces considerably the amplitude and the speed of vertebral movements. Therefore to sum up, one can think that the suicide jumps in a vertical position, from a height chosen to be high enough. He lands more often feet first and the muscular atony increases the mobility of lower limbs and the spine, sharing out the kinetic energy and finally protects the spinal cord.

So may be explained the better recovery of the defenestration paraplegic for the contentment of scientific spirit but not for the satisfaction of a Cartesian mind when seeing that the injured worker remains tetraplegic while the suicidal jumper recovers.

\section{SUMMARY}

The computer study of 783 paraplegics at Henry Gabrielle allows a comparison of the 24 suicidal cases (out of a window) with the 132 non-voluntary falls: 
the suicides are young women (less than 30 years' old) with previous psychiatric history.

The lumbo-sacral vertebral level is found in $24 \cdot \mathrm{I}$ per cent of suicidal cases, as compared to 8 per cent in cases of accident and cervical only 6.9 per cent (to I8.4 per cent for accidental) while dorsal and dorso-lumbar are comparable.

This preponderance of low lesions with better motor-sensitive evolution is surprising. To understand it, some explanations may be put forward: for the suicidal attempts, the height of the fall is generally greater, the body is in a vertical position, feet beneath, and the muscles are relaxed. When reaching the ground the kinetic energy is shared out amongst lower levels (with frequent associated, lesions) and lower part of spine. The comparison is made with the fractures seen when paratroops are landing and when jet pilots are ejecting.

\section{RÉSUMÉ}

L'étude statistique de 783 dossiers de paraplégiques traités à $H$. Gabrielle permet une comparison de 24 tentatives de suicide par defenestration à $\mathrm{I} 32$ chutes accidentelles: les suicidaires sont des femmes jeunes ayant des antécédents psychiatriques.

Le niveau vertébral des lésions a une répartition opposé pour les fractures lombaires (24. I \% des suicides, $8 \%$ des accidentels) et cervicales (respectivement $6.9 \%$ et $18.4 \%$ ) et semblable pour les dorsales. De même, les lésions médullaires sont beaucoup plus souvent basses avec une meilleure évolution dans le cas des défenestrations.

Plusieurs facteurs paraissent responsables: la chute se fait d'un lieu en général plus élevé, en position verticale, pieds en bas et avec un relachement musculaire. Lors du contact avec le sol, l'énergie cinétique est répartie aux membres inférieurs (fréquentes lésions associées) et à la colonne vertébrale, dans ses segments inférieurs. urgence.

La comparaison est faite avec les fractures des parachutistes et des pilotes éjectés en

\section{ZUSAMMENFASSUNG}

Die Aufschlüsselung von 24 Querschnittlähmungen durch Defenestration und von 132 Querschnittlähmungen durch Unfall wirde mittels eines Computers durchgeführt.

Bie den Selbstmordversuchen befinden such die Verletzungen in $24.1 \%$ in Lombosacraler Höhe gegen nur $8 \%$ bei den Unfallverletzten und der Verlauf bei den ersten Fällen ist günstiger.

Die beste Erklärung ist folgende: die Defenestration erfolgt von einem höreren Ausgangspunkt, der Körper ist in senkrechter Position beim Sturz, die Muskulatur ist entspannt und die Zahl der unteren Verletzungen ist $\mathrm{zu}$ vergleichen mit denen die beim Fallschirmspringen beobachtet werden.

\section{REFERENCES}

Castanier, M. (1978). Etude statistique des traumatismes médullaires de Henry Gabrielle. Thèse, Lyon, 1978.

Frankel, H. L., Hancok, D. O., Hyslop, G., Melzak, J., Michaelis, L. S., Ungar, G. M., Vernon, J. D. \& WALSH, J. J. (I969). The value of postural reduction in the initial management of closed injuries of the spine with paraplegia and tetraplegia. Paraplegia, 7, I79-192.

Hoff, J., Chapman, M. (I97I). Vertebral fractures associated with suicide attempts. Proceedings of the I8th V.A. Boston, Oct. 7I, pp. 53-54. 
Minaire, P., Castanier, M., Girard, R., Berard, E., Deidier, Ch. \& Bourret, J. (I977). Epidemiology of spinal cord injury in Rhône-Alpes France. Paraplegia, 16, 76-87.

RotonDo, F. (I975). Spinal injury after ejection in jet pilots = mechanism, diagnosis, follow-up and prevention. Aviation, Space and Environ. Med., June, 842-848.

Teyssandier, J. (I968). Le rachis du parachutiste. Concours Méd., 90, 3767-3773.

ToE, T. (1978). Spinal injuries in Rangoon, Burma. Paraplegia, 16, I18-120.

Verriest, J. P., Martin, F., Viviani, P. (I976). Influence de l'état de la musculature cervicale sur le comportement dynamique du système tête-cou du babouin. Cah. Et. Org. Nat. Séc. Rout., Paris, 39, 3-45. 